\title{
Six Sigma for dynamic capabilities development: becoming more flexible organizations
}

\author{
Paper published in \\ International Journal of Lean Six Sigma (IJLSS)
}

Full citation to this publication:

Gutierrez-Gutierrez, L.; Barrales-Molina, V.; Fernandez-Giordano, M. and López-Morales, B. (2020): "Six Sigma for dynamic capabilities development: becoming more flexible organizations". International Journal of Lean Six Sigma, Vol.1, n.1, pp.35-56.

DOI: https://doi.org/10.1108/IJLSS-10-2018-0115

Thank you for your interest in this publication. 


\title{
Six Sigma for dynamic capabilities development: Becoming more flexible organizations
}

\author{
Gutierrez-Gutierrez, L.; Barrales-Molina, V.; Fernandez-Giordano, M. and \\ López-Morales, B. \\ University of Granada (Spain)
}

\begin{abstract}
Purpose: Once operational benefits of Six Sigma are well recognized in literature, this research advances the strategic advantages of this initiative. Thus, this paper analyses how dynamic capabilities (DCs) mediates the relationship between Six Sigma implementation and organizational flexibility, not discussed in literature yet.

Design/methodology/approach: Data from 66 Six Sigma European firms are employed for a structural equation modelling and additional tests -Baron and Kenny's test and Preacher and Hayes's test-to analyse the mediating role of DCs. Following scholars' recommendations, we have created a second-order factor explained by knowledge absorption, organizational learning and knowledge integration to measure DCs. Flexibility, understood as the capacity for organizational adaptation, is measured through its operational and strategic dimensions.
\end{abstract}

Findings: Our results show a significant relationship between Six Sigma practices - team management and statistical metrics - and DCs. In addition, we find support for a significant relationship between DCs and the operational and strategic dimensions of flexibility. Finally, our results confirm that DCs act as mediating variable in the relationship between Six Sigma practices and flexibility. 
Practical implications: Our study contributes to literature that supports the decision to implement Six Sigma. In particular, key Six Sigma practices are identified for those managers who wish to foster DCs generation and organizational flexibility inside their companies.

Originality/value: This research analyses the relationship between Six Sigma and strategic variables, answering the call for research about Six Sigma influence on longterm organizational success.

Keywords: Continuous improvement, Six Sigma, competitive advantage, organizational learning, knowledge management, flexibility

Paper type: Research paper

\section{Introduction}

Six Sigma is understood as a "change management philosophy" that triggers positive effects in the organizations that implement it (e.g. Choo et al., 2007; Jacobs et al., 2015; Schroeder et al., 2008). Nevertheless, empirical research yield contradictory findings to explain how Six Sigma affects performance (e.g., Braunscheidel et al., 2011; Gutiérrez et al., 2012; Mellat, 2011; Nair et al., 2011; Reosekar and Pohekar, 2014). The studies agree primarily on the positive effects of Six Sigma on operating issues such as cost savings and defect reduction (see Choi et al., 2012; Pande et al., 2000; Harry and Schroeder, 2000; Hilton and Sohal, 2012; Zhang et al., 2016), whereas serious concerns remain about its long-term effects (Mellat, 2011; Nair et al., 2011; Swink and Jacobs, 2012). For example, some scholars agree that Six Sigma's intensive efficiency orientation could eventually damage other long-range variables, such as organizational growth (e.g., Mellat, 2011; Swink and Jacobs, 2012). Thus, it is necessary to address the relationship between Six Sigma implementation and strategic variables. 
In the strategic management literature, the dynamic capabilities (DCs) view has emerged consistently to explain organizational adaptation for its successful survival (Teece et al., 1997). It is considered one of the most vibrant and influential topics in current research (Schilke, 2014; Vogel and Guttel, 2012) and has even been proposed as a new strategic management paradigm (see Teece, 2007). In the research agenda of the DCs view, scholars encourage micro-level analysis to shed light on the creation and action of DCs. Many studies attempt to explain how marketing, human resources or operations strategies can trigger the creation of DCs (e.g. Bruni and Verona, 2009). This new framework is based on the assumption that DCs can be understood as the interaction of cross-functional processes to renew the resource base (Eisenhardt and Martin, 2000). However, more attention has been paid to operations management. The inherently technical nature of some DCs, such as new product development, highlights the fact that the role of operations management is essential to understanding how DCs are employed. An important series of recent papers has thus concentrated on identifying the link between DCs and operations strategies such as quality management (e.g. Anand et al., 2009; Swink and Jacobs, 2012; Witcher et al., 2008), managerial processes, flexibility and outsourcing (e.g. Erbas, 2018; Reuter et al., 2010), supply chain management (e.g. Beske, 2012; McAdam et al., 2017) and product design and control (e.g., Lillis and Szwejczewski, 2012; Newey et al., 2012). Nevertheless, despite the importance of continuous improvement initiatives such as Lean Management or Six Sigma, its possible effects on the development of DCs have not yet been analyzed.

In response to these recent research questions, our paper pursues a twofold objective. On the one hand, we aim to demonstrate that Six Sigma can be closely connected to strategic issues, beyond its expected operational results. To determine this, we analyse whether Six Sigma implementation can be indirectly related to strategic and 
operational flexibility, through DCs development, thereby showing a close connection to organizational adaptation. On the other hand, as to the DCs agenda, our goal is to provide empirical evidence to show that the development of successful DCs can enhance the positive effects of functional best practices, such as Six Sigma, improving, for instance, operational and strategic flexibility.

This study contributes to the literature in various ways. First, our findings provide empirical evidence for prior studies that focus on the long-term value of Six Sigma, which has not received solid, rigorous statistical analysis (Choi et al., 2012). Second, in response to some scholars' research calls (e.g. Bruni and Verona, 2009; Teece, 2007), we analyse the link between a specific operations management strategy and DCs generation. Third, although other empirical papers have demonstrated the positive effect of Six Sigma on performance through its influence on DCs, none of the previous empirical papers has measured the generation of DCs (see Gowen and Tallon, 2005; Swink and Jacobs, 2012). Furthermore, building on recent recommendations in the literature, we have used the most consolidated underlying components of DCs to develop an accurate measurement model (e.g. Barreto 2010). Additionally, our analysis contributes to other studies that confirm the role of DCs as mediating variable between functional best practices and performance as evidence of competitive advantage (e.g., Hsu and Wang, 2012). Our study also is relevant to practitioners because our results support the decision to implement Six Sigma. Key Six Sigma practices are identified for those managers who wish to foster DCs generation inside their companies.

This paper is organized as follows. In the next section, we review the literature on Six Sigma and DCs. We then examine how DCs can mediate the relationship between certain features of Six Sigma adoption and strategic and operational flexibility. In Section 
4, we present a description of the methodology, followed by the results. Finally, we discuss the theoretical and practical implications of the results and conclusions.

\section{Six Sigma and the DCs view}

\subsection{Six Sigma}

Six Sigma can be defined as "an organized, parallel-meso structure to reduce variation in organizational processes by using improvement specialists, a structured method, and performance metrics with the aim of achieving strategic objectives" (Schroeder et al., 2008, p. 540). Despite its success, Six Sigma was originally criticized for not contributing new and different ideas to quality management. However, recent studies make strong arguments for its discriminant validity with respect to other quality management systems (Easton and Rosenzweig, 2012; Schroeder et al., 2008; Shafer and Moeller, 2012; Swink and Jacobs, 2012; Zu et al., 2008). These studies show that Six Sigma includes innovative practices that make it an extremely valuable practice. Table 1 shows the specific practices of Six Sigma based on the studies by Zu et al. (2008) and Schroeder et al. (2008). For instance, $\mathrm{Zu}$ et al. (2008) propose an integrative model to discriminate between traditional quality management practices and specific Six Sigma practices, identifying three specific features of Six Sigma: role structure, structured improvement procedure and focus on metrics. According to these studies, our analysis has focused on two practices that describe specific features of Six Sigma. These practices are team management and statistical metrics usage. Team management refers to the role of team managers (Black Belts) to promote the exchange of ideas and opinions, team mentality and individual motivation. Statistical metrics usage is made up of statistical process control (SPC) and other statistical tools to improve products and processes. 
Many studies have attempted to demonstrate the effects of Six Sigma on organizational performance and capabilities (e.g., Shafer and Moeller, 2012). Among those studies that focus on performance, some show that the effects of Sigma are limited to operational issues, such as project savings, process improvements, on-time deliveries, and reduction of inventory and setup time (e.g. Braunscheidel et al., 2011; Linderman et al., 2006; Zhang et al., 2016). However, other papers support the relationship between Six Sigma and performance whenever a mediating variable is taken into account, for instance, knowledge, innovation processes or quality improvement (see Choi et al., 2012; Sin et al. 2015; Zu et al., 2008).

In addition to the papers that study Six Sigma's effects on performance, some recent scholarly research analyses how Six Sigma can help to develop other organizational capabilities, such as absorptive capacity (see Gutierrez et al., 2012), innovation (Mellat, 2011), shared vision (Gutierrez et al., 2009) and knowledge creation (Anand et al., 2010; Arumugam et al., 2013; Sin et al., 2015). These contributions are building a solid framework to argue that scholars should not only study how Six Sigma can improve performance directly but also determine how this strategy triggers the generation of certain capabilities on which organizational success is built. This new line of research is well-supported by theoretical papers that define the conditions Six Sigma adoption should fulfil to secure these advantageous results (Schroeder et al., 2008). This perspective is thus useful to argue that resources and specific processes are not enough to improve firm performance (Szulanski, 1996). However, capabilities are the organizational transformational process by which resources and specific processes are converted into desirable long term results (Dutta et al., 2005). Thus, our study attempts 
to explain how DCs are the mechanism by which Six Sigma impact strategic and operational flexibility.

\subsection{DCs view}

Following Teece et al. (1997), DCs indicate the firm's abilities to integrate, construct and reconfigure internal and external competences to respond to competitive environments. Thus, research on DCs underscores the importance of firms' adaptation to changing external conditions (Kor and Mesko, 2013).

In studying DCs, theoretical papers have focused on explaining the nature of DCs and the processes by which they are generated. Consequently, it is commonly agreed that they are idiosyncratic, deliberate and regular competences that arise primarily from organizational learning (Ambrosini and Bowman, 2009; Barreto, 2010; Eisenhardt and Martin, 2000; Zahra et al., 2006; Zollo and Winter, 2002). In spite of the idiosyncratic nature of DCs, crucial contributions have divided them into their underlying processes or components. Table 2 shows the most important components proposed in the literature. Following Eisenhardt et al. (2010), this microfoundational perspective of DCs helps us to understand which underlying individual- and group-level actions promote their generation. The micro foundation of DCs defines those common characteristics that facilitate the identification and measurement of any dynamic capability. The most recent empirical papers have employed these components satisfactorily, enabling more accurate comparison of their findings (e.g. Pavlou and El Sawy, 2011; Protogerou et al., 2012).

Insert Table 2 
Further, drawing on the microfoundation perspective, scholars need not consider DCs as a black box but rather can explain the organizational capabilities on which DCs are built. In this specific area, we highlight the importance of three main components: knowledge absorption, organizational learning and knowledge integration. DCs literature proposes that key components for DCs development includes absorptive capacity (Wang and Ahmed, 2007), knowledge management (Nielsen, 2006) and learning mechanisms (Zollo and Winter, 2002). Firstly, firms that have generated DCs show outstanding knowledge absorptive capacity (Newey and Zahra, 2009; Wang and Ahmed, 2007). This capacity enables recognition of the value of external information and the sensing of new opportunities and threats. Secondly, organizational learning is required to assimilate such information and generate new knowledge (Nielsen, 2006). Several deliberate learning mechanisms have been proposed to explain how DCs employ new information to change organizational resources and routines (Macher and Mowery, 2009; Zollo and Winter, 2002). Ultimately, knowledge integration is necessary to embed the new knowledge in organizational capabilities through regular exploitation activities (Nielsen, 2006; Verona and Ravasi, 2003; Zheng et al., 2011). Thus, knowledge absorption, organizational learning and knowledge integration can be considered consolidated components of DCs.

\section{Hypotheses development}

\subsection{Six Sigma and DCs}

The theoretical assumptions of the DCs view lead to consider the positive relationship between Six Sigma and DCs. The fundamental role of DCs is the renewal and reconfiguration of organizational routines based on organizational learning (Winter, 2003; Zollo and Winter, 2002). Therefore, DCs can be generated in those organizations in which employees are encouraged to develop trial and error tests, improvisation and 
imitation (Zahra et al., 2006) or are able to learn from past mistakes and pace of experience (Eisenhardt and Martin, 2000). Six Sigma provides a culture of learning and constant change which permits renewal of the knowledge embedded in organizational routines (Arumugan et al., 2013; Easton and Rosenzweig, 2012; Sin et al., 2015). Further, Six Sigma practices such as supportive leadership and the use of statistical tools such as mapping or streamlining processes plays an important role facilitating learning and knowledge creation (Antony and Gupta, 2018; Arumugan et al., 2013; Choo et al. 2007; Pathiratne et al., 2018; Sin et al., 2015). Thus, Six Sigma practices can be considered triggers of the ideal architecture to create DCs (see Choo et al., 2007; DeMast, 2006).

In particular, to enhance knowledge absorption, organizational learning and knowledge integration, it is positive to implement mechanisms and practices to integrate workers, to increase communication and to facilitate knowledge flow (Barrales-Molina et al., 2015; Cohen and Levinthal, 1990; Lane et al., 2006; Gutierrez-Gutierrez et al., 2018; Zahra and George, 2002). For this purpose, Six Sigma implements its specific role structure, with the creation of specialized positions, such as "Champions" or "Black Belts" (Lloréns et al., 2006; Zu et al., 2008). Availability of resources is a key enabler to create knowledge and to learn (Arumugan et al., 2013; Choo et al. 2007; Sin et al., 2015; Sunder and Antony, 2015). Thus, the usage of these Six Sigma specialized positions, leads to the development and better use of existing knowledge in the organization (Arumugan et al., 2013; DeMast, 2006; Gutierrez et al., 2012; Sin et al., 2015). These positions foster and motivate employees' efforts to absorb, to integrate knowledge and to learn (Senge 1999, p.38, in Choo et al., 2007), through, for instance, the usage communication mechanisms that facilitate the relationship between different sections, enhancing these capacities (Arumugan et al., 2013; Gutierrez et al., 2012). They can also set the guidelines to employees on the knowledge that must be assimilated, directing the 
learning efforts (Choo et al., 2007; Wiklund and Wiklund, 2002; Sin et al., 2015). Learning, knowledge absorption and integration are fundamental for problem solving and these positions are a specific resource devoted to problem solving (Choo et al., 2007; Gutierrez et al., 2012). Further, Six Sigma facilitates the development of a shared vision among team members (Gutierrez et al., 2009), because it enhances similarity between units and employees. Indeed, sharing beliefs, language and even personal characteristics facilitates communication and thus the absorption of new knowledge (Gutierrez et al., 2012), a situation known as "homophily" (Gupta and Govindarajan, 2000). For this purpose, the shared usage of the same statistical tools between the employees contribute to similarity between the work units enhancing knowledge absorption. Six Sigma statistical tools are useful to store and share information, that can be used, for example, in the DMAIC cycle, enabling learning, creating new knowledge and combining it with the existing one (Ghosh and Maiti, 2014; Sin et al., 2015; Sunder and Antony, 2015; Wu and Lin, 2009). In addition, using shared tools and methodologies involves learning behaviours such as constructive discussion inside and outside teams, searching for information, critical observation and problem-solving skills, enhancing knowledge integration, as it happens with other quality management teams (Arumugan et al., 2013; Modarres and Pezeshk, 2017; Molina et al., 2007; Sin et al., 2015; Sunder and Antony, 2015). In sum, we propose the following hypotheses:

Hypothesis 1a. There is a positive relationship between Six Sigma team management and DCs.

Hypothesis 1b. There is a positive relationship between Six Sigma and statistical metrics usage and DCs. 


\subsection{DCs and flexibility}

One of the essential assumptions of the DCs view is that these capabilities are the mechanisms by which firms achieve a sustainable competitive advantage (Teece, 2007; Teece et al., 1997; Verona and Ravasi, 2003; Winter, 2003; Zollo and Winter, 2002). This competitive advantage derived from DCs is based on responsiveness and adaptive capability (Wang and Ahmed, 2007; Zhou and Li, 2010). Following Volberda (1996, 362), "the DCs that endow the firm with flexibility are manifested in their flexibility mix". DCs constitute a source of regular renewal to prevent core competences from becoming core rigidities (Eisenhardt and Martin, 2000). Drawing on Volberda, a firm that has generated DCs should show a high level of strategic, structural and operational flexibility. Although it is easy to argue this relationship between DCs and flexibility theoretically, few empirical works have explored the relationship. Even the studies that have taken both variables into account have not tested their direct influence (e.g., Argawal and Selen, 2009; Barrales-Molina et al., 2013; Cui and Jiao, 2011). Therefore, we focus on strategic and operational flexibility to explore this relationship.

Firstly, strategic flexibility will lead firms to respond rapidly and effectively to environmental shifts (Sanchez, 1995; Shimizu and Hitt, 2004; Volberda, 1996). In other words, strategic flexibility is the agility of top managers to reallocate and reconfigure resources, capabilities and processes (Eisenhardt and Martin, 2000). This agility can be supported and enhanced through DCs such as alliance management and new product development. For example, alliance management could ensure strategic flexibility through external information and resource access (Lee and Park, 2008; Zollo and Singh, 2004). Likewise, new product development provides a regular reconfiguration of resources, processes and capabilities (Barrales-Molina et al., 2015; Bruni and Verona, 2009; Gutierrez-Gutierrez et al., 2018; Newey and Zahra, 2009; Newey et al., 2012). 
Secondly, operational flexibility is related to the agility to reconfigure day-to-day tasks and routines (Volberda, 1996) and is defined as a "shop floor level" of flexibility (Pagell and Krause, 1999). This dimension includes abilities of customization, delivery flexibility, volume flexibility and manufacturing flexibility (Pagell and Krause, 2004; Sánchez, 1995). Indeed, operational flexibility can be considered the most immediate effect of DCs, since their role is to change operating routines (Winter, 2003; Zollo and Winter, 2002). Operational flexibility thus defines the degree to which DCs renew or modify organizational processes, routines, and capabilities. Bearing the foregoing in mind, we have formulated the following pair of hypotheses:

Hypothesis $2 \mathrm{a}$. There is a positive relationship between DCs and strategic flexibility.

Hypothesis $2 \mathrm{~b}$. There is a positive relationship between DCs and operational flexibility.

\subsection{The mediating role of $\mathrm{DCs}$}

Recent studies suggest that Six Sigma can provide a source of adaptation (e.g., Chatterjee, 2003; Gowen and Tallon, 2005; Padhy and Sahu, 2011; Swink and Jacobs, 2012; Thawani, 2004). These contributions argue that some distinctive Six Sigma practices have great potential to promote constant change in culture and to respond to environmental shifts. However, the empirical results on this direct effect do not seem to be conclusive.

As to team management, it is commonly argued that Six Sigma leaders' projects become agents of change within the organization. Due to their extensive training, commitment and involvement, they are able to create an organizational learning climate that increases the organization's agility and updates operational processes (Choo et al, 2007; Gowen and Tallon, 2005; Swink and Jacobs, 2012).Consequently, the level of team management in a Six Sigma project could be positively related to strategic and operational 
flexibility. Master Blacks, Blacks and Green Belts are customer centred, providing essential information to enrich strategic decision-making (Padhy and Sahu, 2011), enhancing strategic flexibility. Additionally, project leaders evaluate whether current routines, processes and tasks are providing accurate results and propose changes in these processes when necessary. This behaviour and involvement also lead us to argue that the level of team management in a Six Sigma project could affect strategic flexibility indirectly.

Statistical metrics usage might also contribute to increasing the level of flexibility. More specifically, the customer-oriented and financial metrics used in Six Sigma projects (Schroeder et al., 2008) provide extremely valuable information for top managers, helping to identify prospective opportunities and threats. Thus, statistical metrics usage could improve the organization's responsiveness and agility when facing environmental shifts, increasing the level of strategic flexibility. Furthermore, the use of statistical tools such as experiments, regressions, flow charts and fishbone diagrams supports a rational analysis to evaluate whether current processes and routines are providing desirable effects, facilitating comprehension of their functioning (De Mast, 2006). In other words, statistical metrics usage provides hard evidence on the efficacy of processes and helps to achieve consensus on good solutions to improve and adapt them (Choo et al., 2007). Consequently, we could argue a prospective relationship between statistical metrics usage and flexibility.

Despite these theoretical arguments, strategic and operational flexibility are complex variables that require other important internal and external factors. Strategic flexibility needs, for instance, speed of strategic change, variety of strategic options, applying new technologies (Sethi and Sethi, 1990; Verdu-Jover et al., 2004; Volberda, 1996). Further, operational flexibility is derived from outsourcing, variation of production 
volume, temporary labour, etc. (Chiang et al., 2012; Sethi and Sethi, 1990; Volberda, 1996). Thus, it is quite difficult fora specific operations management strategy such as Six Sigma perse could improve the level of strategic and operational flexibility. However, other intermediate variables can intervene between Six Sigma practices and flexibility. Thus, DCs through knowledge absorption, integration and learning, can be proposed as the mechanisms by which indirect effects of Six Sigma affect strategic and operational flexibility. In other words, when an organization learns, absorbs and integrates knowledge -DCs microfoundation-, it can take advantage of Six Sigma practices to increase its strategic and operational flexibility. This is consistent with our previous argument to relate DCs and flexibility. We can thus formally state the following hypotheses:

Hypothesis 3a: DCs mediate the relationship between team management and strategic flexibility.

Hypothesis 3b: DCs mediate the relationship between team management and operational flexibility.

Hypothesis 3c: DCs mediate the relationship between statistical metrics usage and strategic flexibility

Hypothesis 3d: DCs mediate the relationship between statistical metrics usage and operational flexibility.

Insert Figure 1

\section{Research methodology}

\subsection{Sample and data collection}


Data were collected through a structured questionnaire from European firms that had adopted Six Sigma. We first pretested a pilot version of the questionnaire through personal interviews with three academics and three managers. These experts reviewed the pilot version to check for ambiguity, incongruity and formatting problems. After incorporating their suggestions, we sent the final version to the CEOs of the study population. We used CEOs as key informants because they usually receive the global information necessary to respond accurately to our questionnaire.

To define this population, we performed successive searches of firm websites, Six Sigma clubs, databases and published papers. Finally, we created a database of 350 European firms that had adopted Six Sigma. Each firm was asked to participate in our study. Due to the low number of firms in the population, we had to devote substantial effort to achieving their involvement in the study. Ultimately, 66 valid responses were collected, achieving a response rate of $18.9 \%$. Other prior Six Sigma studies have employed similar samples to test their hypotheses (e.g., Easton and Rosenzweigh, 2012; Gowen and Tallon, 2005). Nevertheless, we analysed possible bias due to non-respondent firms (Amstrong and Overton, 1977) and found no significant differences in the organizational variables of responding and non-responding firms. Similar tests were developed to compare early and late responses. Table 3 shows a brief description of the demographic features of the sample.

\section{Insert Table 3}

\subsection{Measurement model}

Specific Six Sigma practices 
To determine the extent to which the firm has promoted team management and statistical metrics usage, we used two Likert-type 7 -point scales $(1=$ "totally disagree" to $7=$ "totally agree"). For team management, we adapted a scale designed by Flynn et al. (1995) that have been used in similar empirical studies (e.g., Molina et al., 2007). The set of scales is detailed in Appendix A. For statistical metrics usage, we adapted a scale developed by Ahire et al. (1996). We also analysed the scales' consistency and reliability. Factor analysis showed that the items in each scale loaded on a single factor, providing proof of the scale's unidimensionality. The Cronbach's alpha values for each scale were 0.875 (team management) and 0.948 (statistical metrics usage), indicating an appropriate level of internal consistency.

$D C s$

To measure DCs, we followed the recommendations of several scholars (e.g. Barreto, 2010; Easterby-Smith et al., 2009; Wang and Ahmed, 2007). Firstly, we identified a set of attributes underlying DCs, to create the second-order factor. The second-order factor allows explaining a construct that is composed of a certain number of underlying subconstructs or components, as is the case with DCs development. Based on our literature review, we selected knowledge absorption, organizational learning and knowledge integration. Secondly, we designed a formative model which assumes that DCs are caused by these three attributes. Thus, knowledge absorption, organizational learning, and knowledge integration are the first-order factors used to create the second-order factor that measures DCs. This formative model allows us to approach the abstract and intangible nature of DCs. Formative constructs are recommended for reasons such as (1) the content of each component is not similar and consequently they are not interchangeable, (2) indicators do not have to co-vary with each other, and (3) changes in the components lead to changes in the final construct and not the reverse (Braojos et al., 
2015; Petter et al., 2007; Tamayo-Torres et al., 2019). Similar procedures have been followed by other related empirical papers (e.g., Barrales-Molina et al., 2013; Pavlou and El Sawy, 2011; Protogerou et al., 2012).

For knowledge absorption, we used the scale proposed by Szulanski (1996) in his seminal paper. However, our initial exploratory analysis indicated that three items did not fulfil the necessary conditions (factor loading and individual reliability). Once these three items were eliminated, the reliability of the scale was analysed $(\alpha=0.874)$, as was the unidimensionality. A five-item scale was used to measure organizational learning. These items are based on the scales developed by Sinkula et al. (1997) and Hult and Ferrel (1997). The exploratory analysis indicates that one item should be eliminated ("Once we quit learning we endanger our future"). The Cronbach's alpha of the purified scale is 0.945, showing an acceptable level of internal consistency. We also checked for unidimensionality. As to knowledge integration, following the recommendations of Grant (1996), we used a five-item scale. The exploratory analysis showed that three items had to be eliminated. The final scale is unidimensional and reliable $(\alpha=0.795)$.

After an initial exploratory factor analysis, we developed a confirmatory analysis to determine whether these first-order factors could be considered sub-dimensions of a wider construct. The results of the second-level confirmatory factor analysis are detailed in Fig. 2. The standardized load of each first-order factor is significant and ranges from 0.412 to0.844. Similar studies have obtained equivalent loads (e.g. Pavlou and El Sawy, 2011). The fit indices for this second-level confirmatory analysis were: $\chi^{2}=23.421$ (GFI) $=0.93$, adjusted goodness of fit index $(\mathrm{AGFI})=0.842$, normed fit index $(\mathrm{NFI})=0.97$ comparative fit index $(\mathrm{CFI})=0.99$, root mean square error of approximation (RMSEA) $=0.05$. 


\section{Strategic and operational flexibility}

To determine the level of strategic and operational flexibility, we based our measurement on specific scales included in seminal papers on flexibility. To measure strategic flexibility, we used the scale proposed by Volberda (1999). A preliminary analysis indicated, however, that the last two items should be eliminated. The purified scale shows unidimensionality and reliability $(\alpha=0.760)$. The scale employed to measure operational flexibility was based on scales proposed by Sethi and Sethi (1990) and Chatterjee et al. (1984). The purified scale shows unidimensionality and reliability $(\alpha=0.907)$.

\section{Insert Table 4}

\section{Validity and reliability of scales}

Results of the validation of the final measurement model are detailed in Table 4 tested with EQS 6.1. The robust method has been used for the estimation. The purified scales include items with significant factor loadings ( $\mathrm{t}$-value $>1.96, \mathrm{p}<0.05)$ and individual reliability $\left(\mathrm{R}^{2}\right)$, which exceeds 0.5 . These indicators ensure the convergent validity of the scales. In addition, the composite reliability was evaluated and exceeds the minimum recommended value (0.7). The analysis of average variance extracted also shows that the results for all cases exceed the accepted value (0.5). In conclusion, all scale indicators are within the accepted values, showing that the measurement model is accurate. Likewise, the goodness of fit is demonstrated through absolute $\left(\chi^{2}=1,306.925\right.$; RMSEA $\left.=0.09\right)$, 
incremental $(\mathrm{CFI}=0.97)$ and parsimony $(\mathrm{NNFI}=0.90)$ fit indices. A NNFI and CFI above 0.90 and a RMSEA below 0.08 or 0.10 show a good level of fit in measurement models (Molina et al., 2007). Satisfactory fit can still be obtained when the AGFI does not reach 0.9 but at least exceeds 0.5 (Byrne, 1998; Mulaik et al., 1989). To finish the validation process, we studied the discriminant validity of the set of scales to ensure they measure different constructs. We applied the procedure proposed by Howell (1987) and Szulanski (1996). This analysis confirms that each construct is significantly different. In sum, these tests confirm the unidimensionality, convergent and discriminant validity of measurement model. To conclude this section, Table 5 shows the descriptive statistics and the correlations matrix.

Insert Table 6

\section{Results}

The data analysis method used in this paper is structural equations modelling (SEM) with EQS 6.1. The results of structural model are detailed in Fig. 3. In order to achieve greater clarity, this figure includes only the estimated parameters of structural equations.

Insert Figure 3

Firstly, the fit indices were: $\chi^{2}=1,197.26$, goodness of fit index $(\mathrm{GFI})=0.812$, adjusted goodness of fit index $(\mathrm{AGFI})=0.728$, normed fit index $(\mathrm{NFI})=0.971$, comparative fit index $(\mathrm{CFI})=0.970$, root mean square error of approximation (RMSEA) 
$=0.058$. GFI, AGFI, NFI, and CFI above 0.5, and NFI and CFI above0.9. These levels indicate satisfactory fit (Byrne, 1998; Mulaik et al., 1989).

Secondly, estimated parameters show a positive and significant relationship between specific practices of Six Sigma (team management and statistical metrics usage) and DCs. These results support hypothesis H1a $(0.730$, $\mathrm{t}$-value=4.645) and hypothesis $\mathrm{H} 1 \mathrm{~b}(0.234$, $\mathrm{t}$-value=2.012). In addition, as posited in hypotheses $\mathrm{H} 2 \mathrm{a}$ and $\mathrm{H} 2 \mathrm{~b}$, our results confirm a positive and significant relationship between DCs and both dimensions of flexibility, strategic flexibility $(0.981, \mathrm{t}$-value $=3.063)$ and operational flexibility $(0.970$, t-value $=3.365)$

Thirdly, to test hypothesis H3, we analysed the mediating role of DCs, following the procedures proposed by several authors (e.g., Baron and Kenny, 1986; Preacher and Hayes, 2008). According to Baron and Kenny (1986), direct and indirect effects must be evaluated using several steps. The results derived from this test are presented in Table 6. The first step is to analyse the isolated direct effects between independent and dependent variables. Fig. 4 presents the estimated parameters. The next step is to confirm that independent variables are positively related to DCs and that this mediator variable is related to the dependent variables. This step was confirmed previously with hypotheses $\mathrm{H} 1$ and H2. The last step requires analysing whether the direct effects of independent variables on dependent variables dropped due to the inclusion of the mediator variable. Fig. 3 allows us to observe that this condition is fulfilled for every independent variable. In addition, since the inclusion of DCs produced non-significant parameters in direct relationships, the results support full mediation (Baron and Kenny, 1986). However, the mediation effect of DCs in the relationship between statistical metrics usage and operational flexibility cannot be confirmed using this test, since the direct relationship was not significant in Step 1 (although the direct effect did drop with inclusion 
variable).Consequently, we also performed the test suggested by Preacher and Hayes (2008). This test is recommended especially for small sample sizes. According to these authors, a bootstrap method must be developed to test the mediation. Table 7 shows the results of this assessment. Following Hayes (2009), we have performed 5,000 resamples and calculated three different bootstrap confidence intervals: percentile, bias-corrected (BC) and bias-corrected accelerated (BCa). To confirm that indirect effects are significantly different from zero with a $95 \%$ confidence level, each interval calculated must not contain zero. As can be observed, zero is not contained in each confidence interval calculated, confirming full mediation for all of the hypotheses. Therefore, DCs fully mediate the relationship of Six Sigma specific practices to strategic and operational flexibility.

Insert Table 6

Insert Figure 4

Insert Table 7

\section{Discussion and conclusions}

\subsection{Discussion of results}


The results of our findings on Six Sigma contribute to recent stream of the literature that tests its impact on organizational success. Whereas the literature strongly supports positive operational benefits derived from Six Sigma (see Choi et al., 2012; Hilton and Sohal, 2012; Zhang et al., 2016), there is no general agreement regarding its long term effects. Our results show a positive relationship between Six Sigma implementation and DCs development, supported for both specific practices of Six Sigma considered: team management and statistical metrics usage. Although some prior studies have suggested this relationship (e.g. Gowen and Tallon, 2005; Swink and Jacobs, 2012), our study measures DCs effectively. In addition, our finding is consistent with studies that have observed the direct and positive relationship between Six Sigma and organizational knowledge-related capabilities (Anand et al., 2010; Arumugam et al., 2013; Gutierrez et al. 2009; 2012; 2016; Sin et al., 2015). Our research advances this line of research by showing how these positive relationships are also observed in an integrated structure composed of knowledge absorption, organizational learning and knowledge integration.

This first finding also represents a relevant contribution to both operations management and the DCs view. Firstly, it has been demonstrated that Six Sigma can create a desirable learning infrastructure for developing DCs. Few specific operations strategies have been considered so advantageous for organizational learning and adaptation. Secondly, these results respond to some research calls from the DCs literature to advance in the explanation of DCs by using functional strategies (Easterby-Smith et al., 2009; Vogel and Guttel, 2012). In other words, the confirmation of this relationship posits a preliminary connection between Six Sigma and organizational success.

As to the link between DCs and flexibility, our results support a positive relationship between DCs and strategic and operational flexibility. Whereas sustainable competitive advantage has been recognized as the key effect derived from DCs (Teece et 
al., 1997; Teece, 2007), the most direct sign of DCs generation is a high degree of controllability or agility of the organization (Sambamurthy et al., 2003; Volberda, 1996). Such control of the firm requires extraordinary levels of strategic and operational flexibility. Although this assumption has been widely recognized in the literature, no empirical paper has explored this relationship. Thus, our work contributes to the DCs view by explaining that firms that develop DCs successfully can expect higher levels of strategic and operational flexibility. In addition, these findings add empirical evidence to previous studies that have proven flexibility capability to be an antecedent in achieving adaptation and competitive advantage to survive in hypercompetitive environment (e.g., Cui and Jiao, 2011).

Our research is also relevant in that it observes DCs as mediating variable. Recent empirical studies have explained how DCs enable other resources and capabilities to have an effective impact on strategic variables such as performance or competitive advantage (e.g., Hsu and Wang, 2012). Our results also confirm that DCs fully mediate the relationship between Six Sigma practices and flexibility. This is a significant finding because it helps us to understand the nature of the relationship between Six Sigma and flexibility. According to our results, DCs are important mechanisms underlying this relationship. Firms that wish to take advantage of benefits derived from Six Sigma should develop DCs. In other words, DCs play a key role in governing the relationship between Six Sigma and flexibility. It could thus be argued that part of the controversy identified in the results obtained on Six Sigma and performance can be explained through the absence of a common mediating structure. Our study may therefore open a new path for research based on the identification of common mediating variables that explain the relationship between Six Sigma and additional strategic variables. 
Finally, our study sheds light on a debate that has emerged recently within the Six Sigma literature. Several scholars claim that Six Sigma enhances behaviors that benefit primarily exploitation activities, damaging those related to exploration (Schroeder et al., 2008; Swink and Jacobs, 2012). However, our results demonstrate that Six Sigma is closely related to knowledge absorption, organizational learning and knowledge integration. Our study thus confirms that Six Sigma can generate an organizational learning structure that could contribute to both exploratory knowledge integration and exploitative activities. This result suggests that organizations may become more ambidextrous by implementing Six Sigma (Alcaide-Muñoz and Gutierrez-Gutierrez, 2017; Mellat, 2011; Schroeder et al., 2008). These findings are consistent with Schroeder et al. (2008), who justify theoretically how Six Sigma also facilitates exploratory behaviors through the roles of Black Belts, since these roles combine strategic, tactical and operational activities. In particular, these results have been supported when considering both team management and statistical metrics usage as independent variables. Our results thus provide empirical evidence for the literature on the benefits of both of these practices (Nair et al., 2011; Schroeder et al., 2008; Zu et al., 2008).

\subsection{Managerial implications}

The discussion developed in the previous section suggests a series of managerial recommendations aimed at fostering the advantages associated with Six Sigma implementation. Firstly, the results obtained provide important support for understanding the benefit derived from Six Sigma adoption. Whereas studies to date have primarily highlighted its operational benefits, our findings show how this initiative allows the organization to achieve additional strategic advantages. Specifically, Six Sigma is structured on a series of specific practices that contribute to DCs development. Thus, Six Sigma practices can lead to better organizational adaptation to the environmental shifts 
and consequently, contribute to organizational success, in current hypercompetitive environments.

Secondly, managers seeking to develop knowledge-related capabilities such as knowledge absorption, organizational learning and knowledge integration may consider Six Sigma as an alternative that allows them to enhance these capabilities. Further, benefits from improvements in operational and strategic flexibility through DCs development constitute added value to added value for Six Sigma be Six Sigma implementation.

Thirdly, the identification of the specific Six Sigma practices related to DCs generation provides managers some practical guidelines on how to implement this initiative successfully. Appropriate team management is essential in this effort. Team managers must facilitate employees' communication, encouraging the balance between tactical and strategic priorities. Furthermore, this structure must be accompanied by statistical usage metrics that facilitate the exchange of work between employees in achieving the objectives. DCs development in Six Sigma organizations thus requires both a strong, solid team structure, well managed and accompanied by comprehensive training, and appropriate use of statistical methods.

Finally, our findings could help managers to understand why some firms that have implemented Six Sigma have not achieved better results. Our study demonstrates that DCs govern the relationship between Six Sigma and desirable effects such as flexibility. Thus, organizations that have made the decision to implement Six Sigma should promote knowledge absorption, organizational learning and knowledge integration, as these three capabilities are the underlying components that enable DCs generation.

\subsection{Limitations and future lines of research}


This study has certain limitations that must be considered for results generalization. Firstly, the firms included in the survey fulfill only the condition of having implemented Six Sigma projects. This limitation prevents us from analyzing additional information on the Six Sigma projects, such as current implementation stage, number of projects initiated, and number of specialists involved — information that could enrich our results substantially. Secondly, the data used are based on subjective perceptions from a single respondent. Future research could focus on this line, taking into account more respondents or objective data or developing case studies. Thirdly, the sample of the study includes exclusively European companies that can limit its generalization to this cultural context. Future complementary studies that analyze these behaviors, for example, in American or Asian companies, would be recommendable. Finally, this is a cross-sectional study. Due to the nature of DCs, time-series or longitudinal data would be more appropriate for evaluating long-term expected results. We conclude that the most vibrant future lines of research could focus on how specific Six Sigma firm adopters have been able to achieve great levels of flexibility and adaptation. 
Table 1. Specific Six Sigma practices

\begin{tabular}{|c|c|c|}
\hline Authors & $\begin{array}{c}\text { Specific Six } \\
\text { Sigma practices }\end{array}$ & Definition \\
\hline \multirow{3}{*}{$\begin{array}{l}\text { Zu et al. } \\
(2008)\end{array}$} & $\begin{array}{l}\text { Six Sigma role } \\
\text { structure }\end{array}$ & $\begin{array}{l}\text { The organization uses a group of improvement specialists who are } \\
\text { developed through Six Sigma training and certification programs. The } \\
\text { improvement specialists are classified with different ranks based on their } \\
\text { expertise. The specialists are assigned with specific leadership roles and } \\
\text { responsibilities in improvement teams. }\end{array}$ \\
\hline & $\begin{array}{l}\text { Six Sigma } \\
\text { structured } \\
\text { improvement } \\
\text { procedure }\end{array}$ & $\begin{array}{l}\text { There is an emphasis on following a standardized procedure in planning } \\
\text { and conducting improvement projects or design projects. Teams apply the } \\
\text { appropriate QM tools and techniques as prescribed in each step of the } \\
\text { structured procedure. }\end{array}$ \\
\hline & $\begin{array}{l}\text { Six Sigma focus } \\
\text { on metrics }\end{array}$ & $\begin{array}{l}\text { Quantitative metrics are used to measure process performance and } \\
\text { product quality performance, and set project goals. Business-level } \\
\text { performance measures and customer expectations are integrated with } \\
\text { process-level performance measures. }\end{array}$ \\
\hline \multirow{4}{*}{$\begin{array}{l}\text { Schroeder } \\
\text { et al. (2008) }\end{array}$} & $\begin{array}{l}\text { Parallel-meso } \\
\text { structure }\end{array}$ & $\begin{array}{l}\text { Employment of Six Sigma teams led by Black Belts and supported by } \\
\text { Champions who focused on improving the organization, achieving } \\
\text { multilevel integration. Strategic project selection and leadership } \\
\text { engagement. }\end{array}$ \\
\hline & $\begin{array}{l}\text { Improvement } \\
\text { specialists }\end{array}$ & Existence of full-time improvement specialists called Black Belts \\
\hline & $\begin{array}{l}\text { Structured } \\
\text { method }\end{array}$ & $\begin{array}{l}\text { Method for processes improvement DMAIC (define, measure, analyze, } \\
\text { improve and control). Employment of quality tools such as statistical } \\
\text { process control or cause-effect charts. }\end{array}$ \\
\hline & $\begin{array}{l}\text { Performance } \\
\text { metrics }\end{array}$ & $\begin{array}{l}\text { Usage of special metrics, including process sigma measurement, critical } \\
\text { to quality metrics, financial measures and strategic measures. }\end{array}$ \\
\hline
\end{tabular}

Table 2. Proposed components of dynamic capabilities

\begin{tabular}{cc}
\hline Authors & Components of DCs \\
\hline Teece et al. (1997) & Sensing capability \\
Learning capability \\
Integrating capability \\
Coordinating capability \\
\hline Nielsen (2006) & Knowledge development \\
& Knowledge recombination \\
& Knowledge use \\
Teece (2007) & Sensing capability \\
& Seizing capability \\
& Reconfiguring capability \\
Wang and Ahmed (2007) & Absorptive capability \\
& Innovative capability \\
& Adaptative capability \\
\hline
\end{tabular}


Table 3. Demographic features of the sample

\begin{tabular}{cc}
\hline & $\mathbf{3 0 . 3 0 \%}$ Machinery and components \\
& $\mathbf{2 5 . 7 5 \%}$ Services \\
Economy sector & $\mathbf{2 1 . 2 1 \%}$ Electricity and electronics \\
& $\mathbf{2 2 . 7 2 \%}$ Miscellaneous sectors \\
\hline \multirow{3}{*}{ Number of employees } & $\mathbf{3 7 . 8 7 \%} 51-250$ employees \\
& $\mathbf{3 6 . 3 6 \%} 251-1000$ employees \\
& $\mathbf{2 5 . 7 5 \%}$ Over 1000 employees \\
\hline Countries & $\mathbf{4 8 . 4 8 \%}$ Spain \\
& $\mathbf{1 9 . 6 9 \%}$ Italy \\
& $\mathbf{1 8 . 1 8 \%}$ Austria \\
& $\mathbf{1 3 . 6 3 \%}$ United Kingdom
\end{tabular}

Table 4. Measurement model

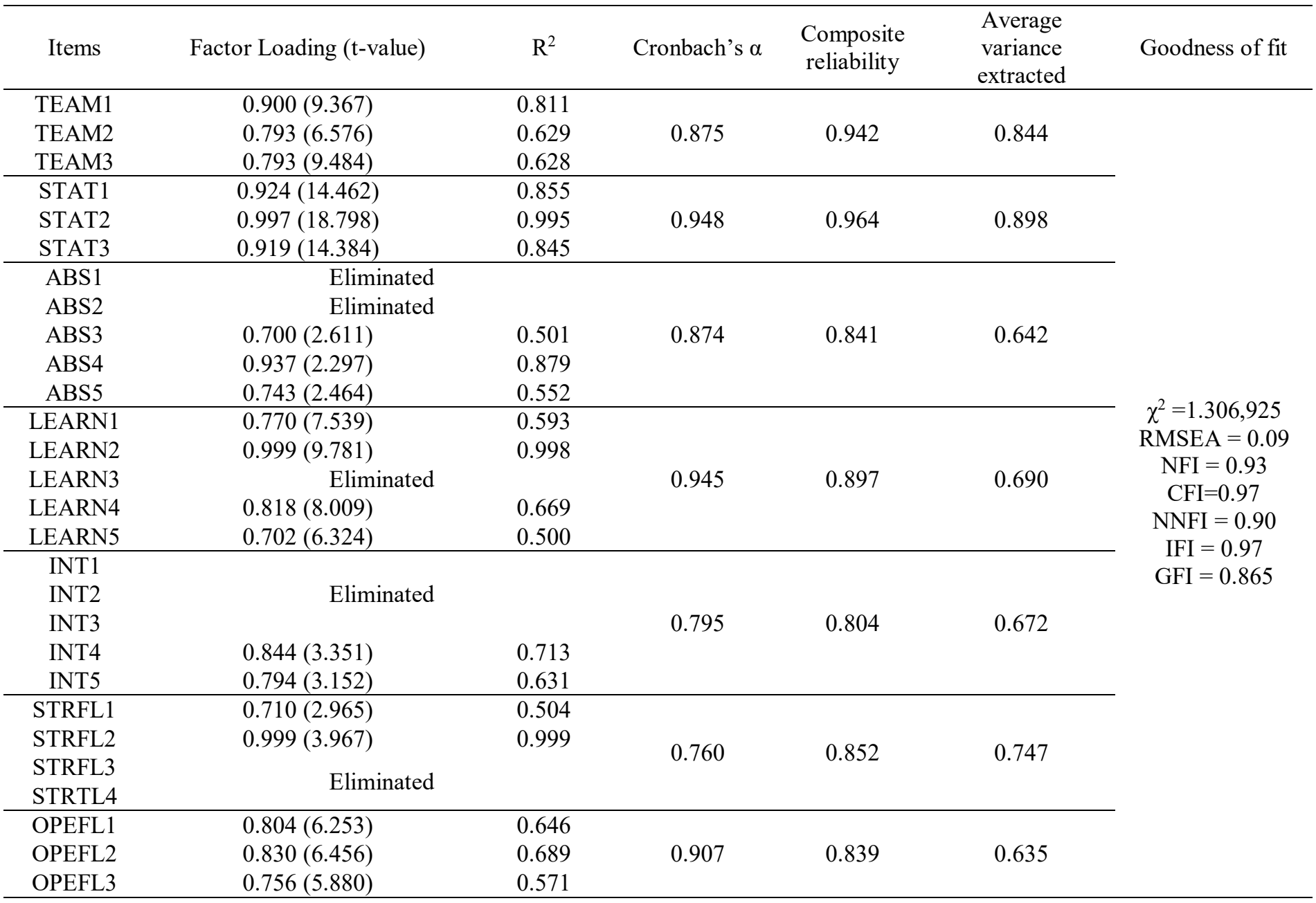


Table 5. Descriptive statistics

\begin{tabular}{|c|c|c|c|c|c|c|c|c|}
\hline Variable & Mean & s. $d$. & 1 & 2 & 3 & 4 & 5 & 6 \\
\hline 1. Team management & 5.20 & 1.22 & & & & & & \\
\hline $\begin{array}{c}\text { 2. Statistical metrics } \\
\text { usage }\end{array}$ & 4.59 & 1.94 & 0.16 & & & & & \\
\hline $\begin{array}{l}\text { 3. Knowledge } \\
\text { absorption }\end{array}$ & 5.55 & 0.98 & $0.34 * *$ & 0.19 & & & & \\
\hline $\begin{array}{l}\text { 4. Organizational } \\
\text { learning }\end{array}$ & 5.80 & 1.21 & $0.41 * *$ & 0.18 & $0.32 * *$ & & & \\
\hline $\begin{array}{l}\text { 5. Knowledge } \\
\text { integration }\end{array}$ & 5.19 & 1.28 & $0.61 * *$ & $0.25^{*}$ & $0.31 * *$ & $0.52 * *$ & & \\
\hline 6. Strategic flexibility & 5.71 & 1.24 & $0.41 * *$ & 0.12 & $0.38^{* *}$ & $0.51 * *$ & $0.48 * *$ & \\
\hline $\begin{array}{l}\text { 7. Operational } \\
\text { flexibility }\end{array}$ & 4.84 & 1.19 & $0.36^{* *}$ & 0.20 & $0.26^{*}$ & $0.48 * *$ & $0.47 * *$ & $0.48^{* *}$ \\
\hline
\end{tabular}

Table 6. Summary of mediating effect: Baron and Kenny's test

\begin{tabular}{|l|l|c|c|c|c|}
\hline \multicolumn{2}{|c|}{ Hypothesis } & $\begin{array}{c}\text { Isolated } \\
\text { direct } \\
\text { effects } \\
\text { (Fig. 4) }\end{array}$ & $\begin{array}{c}\text { Direct effects in } \\
\text { structural model } \\
\text { (Fig. 3) }\end{array}$ & $\begin{array}{c}\text { Indirect effects } \\
\text { (Fig. 3) }\end{array}$ & Conclusion \\
\hline H3(a) & $\begin{array}{l}\text { Team management } \rightarrow \\
\text { strategic flexibility }\end{array}$ & $0.561^{* *}$ & $-0.269(-1.034)$ & $0.730^{* *} \times 0.981 * *$ & Full mediation \\
\hline H3(b) & $\begin{array}{l}\text { Team management } \rightarrow \\
\text { operational flexibility }\end{array}$ & $0.619 * *$ & $-0.264(-1.144)$ & $0.730^{* *} \times 0.970^{* *}$ & Full mediation \\
\hline & & & & & \\
\hline H3(c) & $\begin{array}{l}\text { Statistical metrics usage } \rightarrow \\
\text { strategic flexibility }\end{array}$ & $0.365^{* *}$ & $-0.025(-0.163)$ & $0.234^{*} \times 0.981^{* *}$ & Full mediation \\
\hline H3(d) & $\begin{array}{l}\text { Statistical metrics usage } \rightarrow \\
\text { operation flexibility }\end{array}$ & 0.184 & $-0.167(-1.263)$ & $0.234 * * 0.970^{* *}$ & Not confirmed \\
\hline
\end{tabular}

$* * \mathrm{p}<0.01 ; * \mathrm{p}<0.05$

Mediator variable: dynamic capabilities

Table 7. Summary of mediating effect: Preacher and Hayes's test

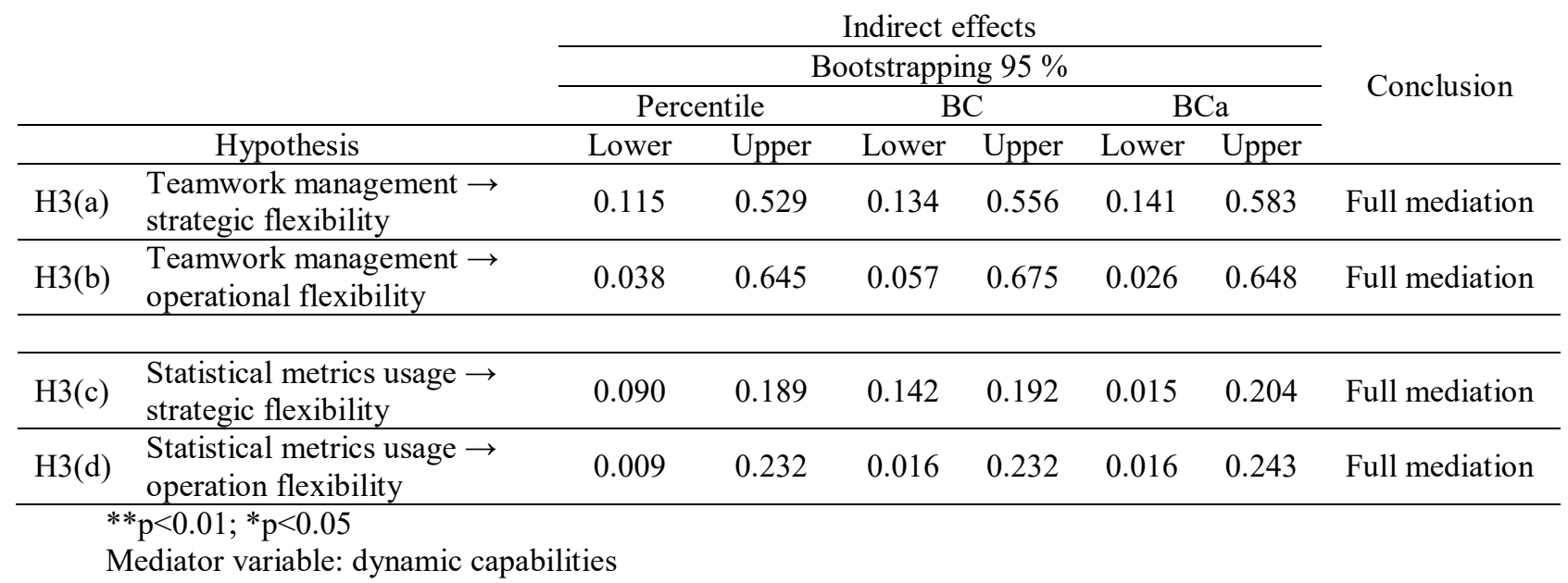


Figure 1. Proposed model

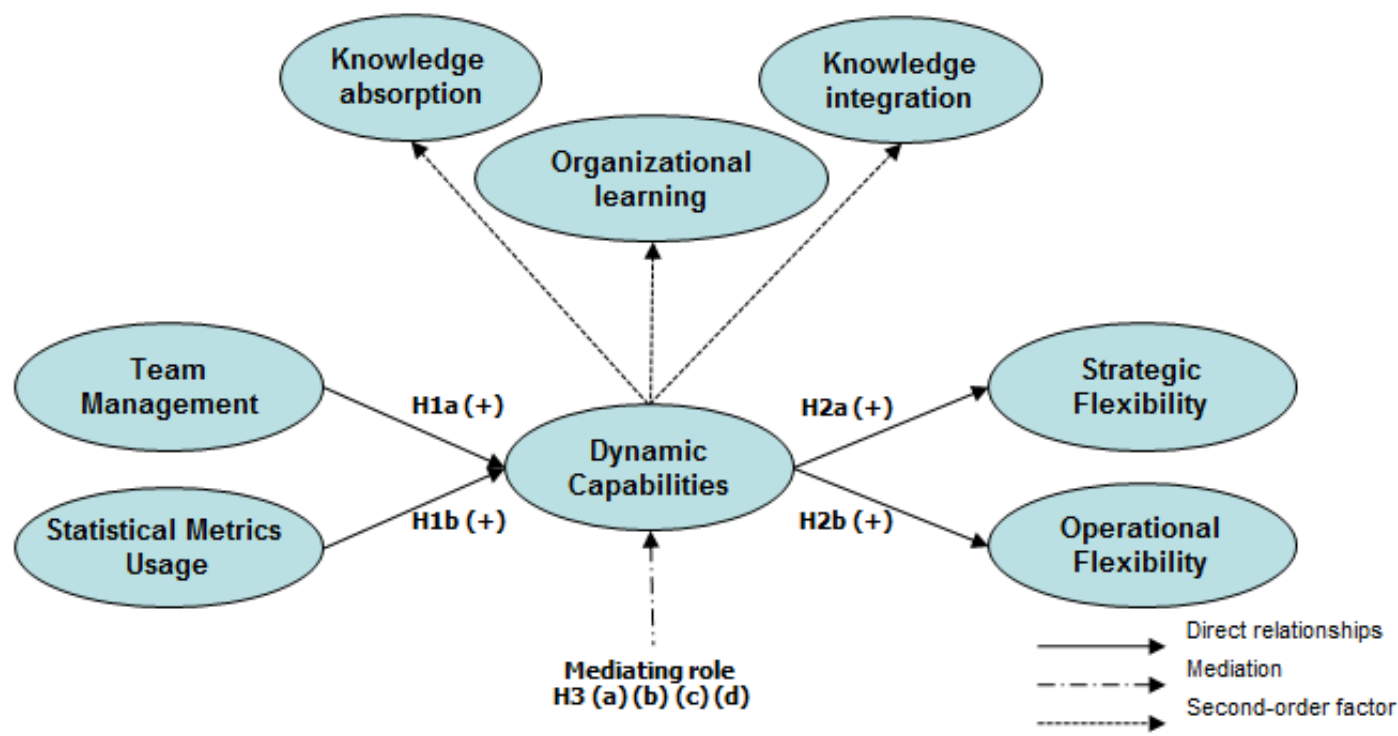

Figure 2. Second-order factor

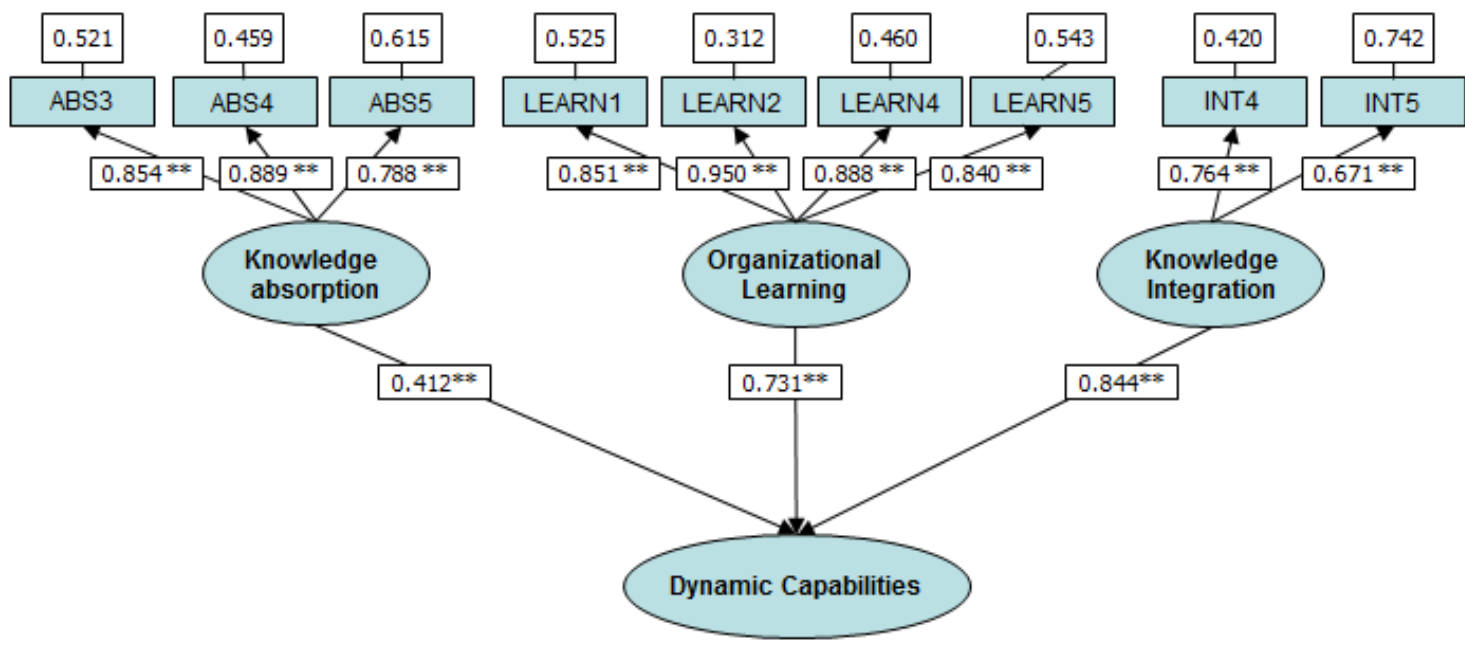


Figure 3. Structural model

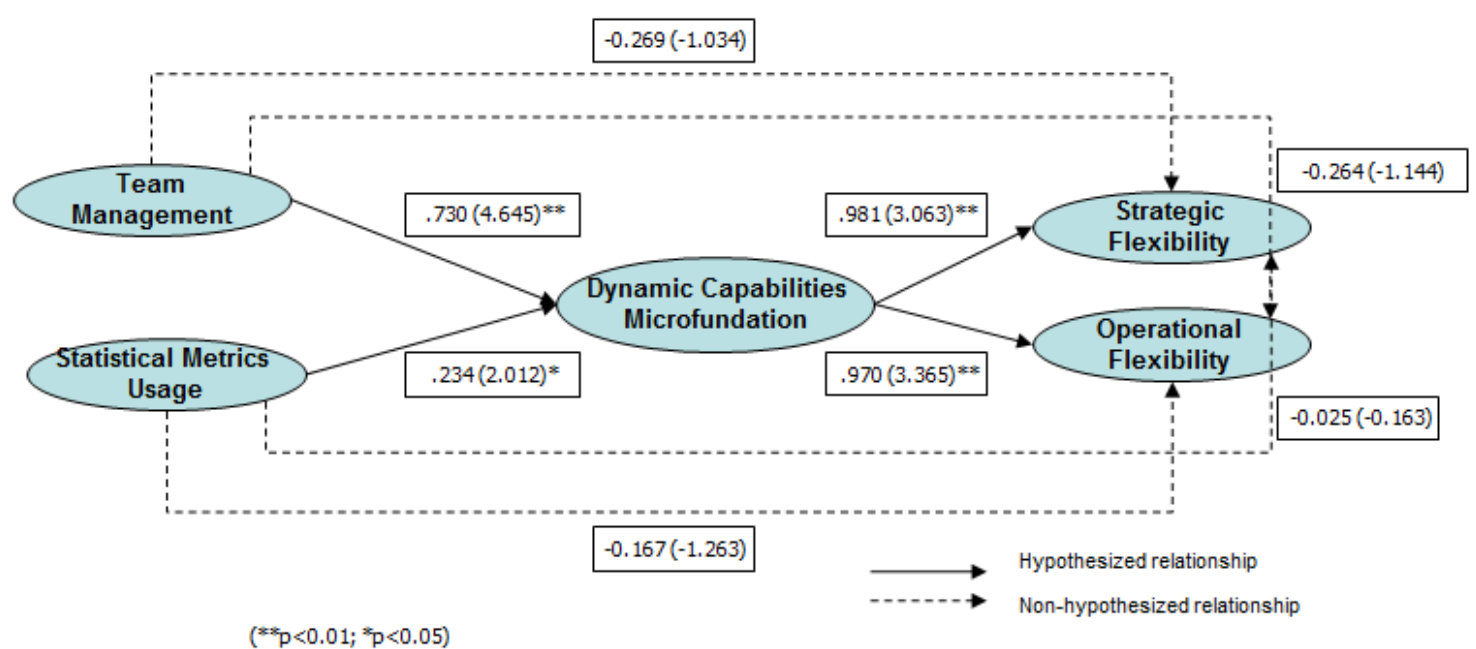

Figure 4. Isolated direct effects
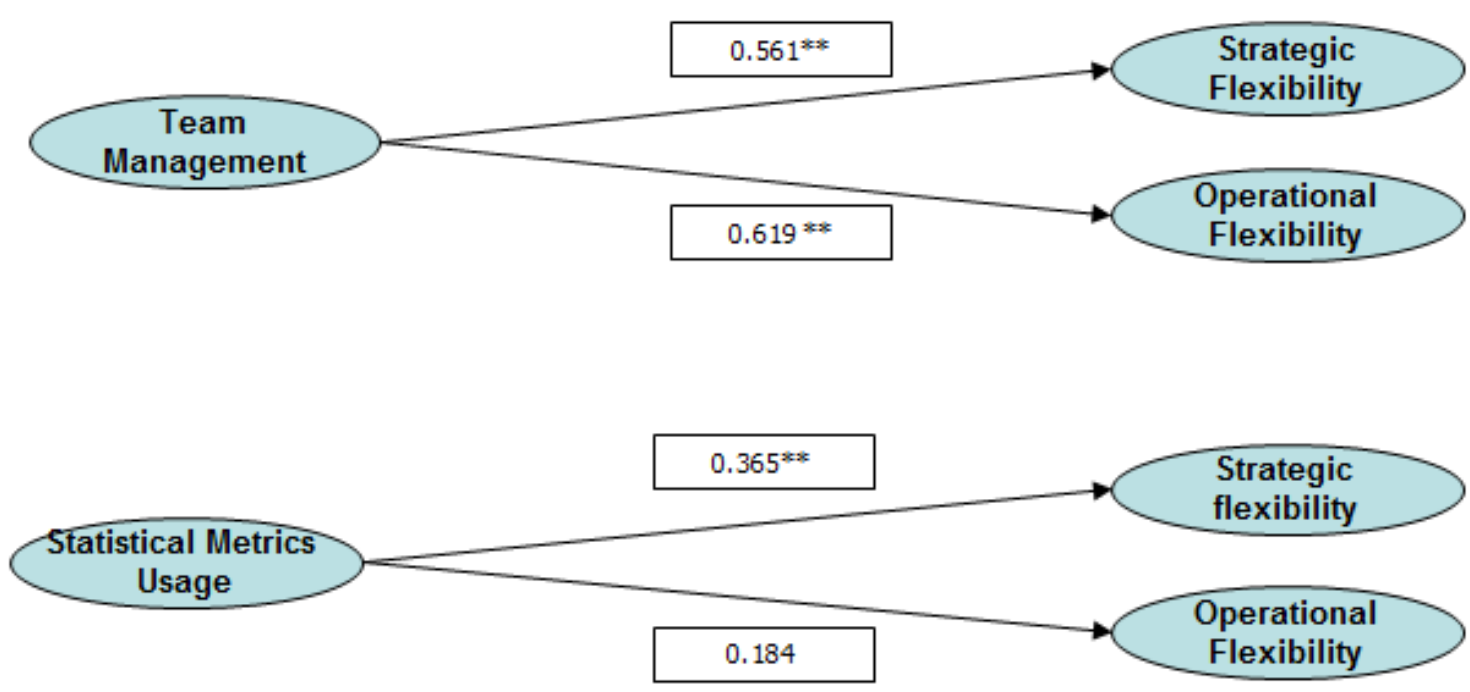

$(* * p<0.01 ; * p<0.05)$

\section{References}

Ahire, S.L., Golhar, D.Y. and Waller, M.A. (1996), "Development and validation of TQM implementation constructs", Decision Sciences, Vol.27 No.1, pp.23-56. 
Alcaide-Muñoz, C. and Gutierrez-Gutierrez, L. (2017), "Six Sigma and organisational ambidexterity: a systematic review and conceptual framework", International Journal of Lean Six Sigma, Vol.8, No.4, pp.436-456

Ambrosini, V. and Bowman, C. (2009), "What are dynamic capabilities and are they a useful construct in strategic management?", International of Management Review, Vol.11, pp.29-49.

Amstrong, J.S. and Overton, T.S. (1977), "Estimating nonresponse bias in mail surveys", Journal of Marketing Research, Vol.14, No.3, pp.396-402.

Anand, G., Ward, P. T. and Tatikonda, M. V. (2010), "Role of Explicit and Tacit Knowledge in Six Sigma Projects: An Empirical Examination of Differential Project Success", Journal of Operations Management, Vol.28, No.4, pp.303-315.

Anand, G., Ward, P. T., Tatikonda, M. V. and Schilling, D. A. (2009), "Dynamic capabilities through continuous improvement infrastructure", Journal of Operations Management, Vol.27, pp.444-461.

Antony, J. and Gupta, S. (2018), “Top ten reasons for process improvement project failures". International Journal of Lean Six Sigma, Forthcoming. https://doi.org/10.1108/IJLSS-11-2017-0130

Arumugam, V., Antony, J. and Kumar, M. (2013), "Linking learning and knowledge creation to project success in Six Sigma projects: An empirical investigation”, International Journal of Production Economics, Vol.141, pp.388-402.

Baron, R.M. and Kenny, D.A. (1986), “The moderator-mediator variable distinction in social psychological research: conceptual, strategic, and statistical considerations", Journal of Personality and Social Psychology, Vol.51, pp.1173-1182. 
Barrales-Molina, V., Bustinza, O. F. and Gutiérrez-Gutiérrez, L.J. (2013), “Explaining the causes and effects of dynamic capabilities generation: a multiple-indicator multiplecause modeling approach”, British Journal of Management, Vol.24, No.4, pp.571-591.

Barrales-Molina, V., Llorens Montes, F.J. and Gutierrez-Gutierrez, L. (2015), "Dynamic capabilities, human resources and operating routines: A new product development approach", Industrial Management \& Data Systems, Vol.115, No.8, pp.1388-1411

Barreto, I. (2010), "Dynamic capabilities: a review of past research and an agenda for the future", Journal of Management, Vol.36, pp.256-280.

Beske, P. (2012), "Dynamic capabilities and sustainable supply chain management", International Journal of Physical Distribution \&Logistics Management, Vol.42, pp.372387.

Braojos-Gomez, J., Benitez-Amado, J., and Llorens-Montes, F.J. (2015). “How do small firms learn to develop a social media competence?" International Journal of Information Management, Vol.35, pp.443-458.

Braunscheidel, M. J.,Hamister, J. W., Suresh, N. C. and Star, H. (2011), “An institutional theory perspective on Six Sigma adoption", International Journal of Operations \& Production Management, Vol.31, No.4, pp.423-451.

Bruni, D. S. and Verona, G. (2009), "Dynamic marketing capabilities in science-based firms: an exploratory investigation of the pharmaceutical industry", British Journal of Management, Vol.20, pp.101-117.

Byrne, B.M. (1998). Structural Equation Modelling with Lisrel, Prelis and Simplis: Basic concepts, Application, and Programming. Lawrence Erlbaum, Mahwah, NJ. 
Chatterjee, A. (2003), "Innovating Growth through "Six Sigma": A Strategic Approach for Combining Robustness with Flexibility", Global Journal of Flexible Systems Management, Vol.4 No.3, pp.33-37.

Chatterjee, A., Cohen, M., Maxwell, W. and Miller, R. (1984), "Manufacturing Flexibility: Models and Measurements". Proceedings of the $1^{\text {st }}$ ORSA/TIMS Conference on FMS, Ann Arbor, MI, pp.49-64.

Chiang, C. Y., Kocabasoglu-Hilmer, C., Suresh, N. (2012), “An empirical investigation of the impact of strategic sourcing and flexibility on firm's supply chain agility", International Journal of Operations \& Production Management, Vol.32, No.1, pp.49-78.

Choi, B., Kim, J., Leem, B., Lee, C. and Hong, H. (2012), "Empirical analysis of the relationship between Six Sigma management activities and corporate competitiveness", International journal of Operations \& Production Management, Vol.32, No.5, pp.528550.

Choo, A. S., Linderman, K. W. and Schroeder, R. G. (2007), "Method and context persectives on learning and knowledge creation in quality management", Journal of Operations Management, Vol.25, pp.918-931.

Cohen, W. and Levinthal, D. (1990), Absorptive capacity: a new perspective on learning and innovation, Administrative Science Quarterly, Vol.35, No.1, pp.128-152.

Cui, Y. and Jiao, H. (2011), "Dynamic capabilities, strategic stakeholders alliances and sustainable competitive advantage: evidence from China", Corporate Governance, Vol.11, No.4, pp.386-398.

De Mast, J. (2006), "Six Sigma and competitive advantage", Total Quality Management, Vol.17, No.4, pp.455-464. 
Dutta, S., Narasimhan, O. and Rajiv, S. (2005), "Conceptualizing and measuring capabilities: methodological and empirical application”, Strategic Management Journal Vol.26, pp.277-285.

Easterby-Smith, M., Lyles, M. A. and Peteraf, M. A. (2009), "Dynamic capabilities: current debates and future directions", British Journal of Management Vol.20, pp.1-8.

Easton, G.S. and Rosenzweig, E.D. (2012), "The role of experience in six sigma project success: An empirical improvements projects", Journal of Operations Management, Vol.30, pp.481-493.

Eisenhardt, K. M. and Martin, J. A. (2000), “Dynamic capabilities: What are they?”, Strategic Management Journal, Vol.21, No.10/11, pp.1105-1121.

Eisenhardt, K. M., Furr, N. R. and Bingham, C. B. (2010), "Microfoundations of performance: Balancing efficiency and flexibility in dynamic environments", Organizational Science, Vol.21, No.6, pp.1263-1273.

Erbaş, E. (2018). "Organisational ambidexterity and industrial clockspeed theories in understanding dynamic managerial capabilities: a multiple case study". International Journal of Business Environment, Vol.10, No.2, pp.174-190.

Flynn, B. B., Schroeder, R. G. and Sakakibara, S. (1995), "The impact of quality management practices on performance and competitive advantage". Decision Sciences, Vol.26, No.5, pp.659-691.

Gowen, C.R. and Tallon, W.J. (2005), "Effect of technological intensity on the relationships among Six Sigma design, electronic business, and competitive advantage: a dynamic capabilities model study", Journal of High Technology Management, Vol.16, No.1, pp.59-87. 
Grant, R.M. (1996), "Toward a knowledge-based theory of the firm", Strategic Management Journal, Vol.17, pp.109-122.

Gutierrez-Gutierrez, L., Barrales-Molina, V. and Kaynak, H. (2018), “The role of human resource-related quality management practices in new product development: A dynamic capability perspective", International Journal of Operations \& Production Management, Vol.38, No.1, pp.43-66.

Gutierrez-Gutierrez, L., Barrales-Molina, V., and Tamayo-Torres, J. (2016), "The knowledge transfer process in Six Sigma subsidiary firms", Total Quality Management \& Business Excellence, Vol.27, No.5-6, pp.613-627.

Gutierrez, L. J., Bustinza, O. F. and Barrales-Molina, V. (2012), "Six Sigma, absorptive capacity and organizational learning orientation", International Journal of Production Research, Vol.50, No.3, pp.661-675.

Gutierrez, L.J., Lloréns-Montes, F.J. and Bustinza, O.F. (2009), “Six Sigma: from a goaltheoretic perspective to shared-vision development", International journal of Operations \& Production Management, Vol.29, No.2, pp.151-169.

Harry, J.F. and Schroeder, R. (2000), Six Sigma. The breakthrough Management Strategy Revolutionizing the World's Top Corporation. Doubleday, New York.

Hayes, A.F. (2009), "Beyond Baron and Kenny: statistical mediation analysis in the new millennium". Communication Monographs, Vol.76, pp.408-420.

Hilton, R. J. and Sohal, A. (2012), “A conceptual model for the successful deployment of Lean Six Sigma”. International Journal of Quality and Reliability Management, Vol.29, No.1, pp.54-70. 
Howell, R. (1987), “Covariance Structure modeling on the personal computer”, Journal of Marketing Research, Vol.24, No.4, pp.456-459.

Hsu, L.C. and Wang, C.H. (2012), "Clarifying the effect of intellectual capital on performance: the mediating role of dynamic capability", British Journal of Management, Vol.23, No.3, pp.179-205.

Hult, G.T.M. and Ferrell, O.C. (1997), “A global learning organization structure and market information processing", Journal of Business Research, Vol.40, No.2, pp.155166.

Kor, Y.Y. and Mesko, A. (2013), “Dynamic managerial capabilities: Configuration and orchestration of top executives' capabilities and the firm's dominant logic", Strategic Management Journal, Vol.34, No.2, pp.233-244.

Lane, P.J., Koka, B. and Pathak, S. (2006), "The reification of absorptive capacity: a critical review and rejuvenation of the construct", Academy of Management Review, Vol.31, No.4, pp.833-863.

Lee, H.U. and Park, J.H. (2008), “The influence of top management team international exposure on international alliance formation”, Journal of Management Studies, Vol.45, pp.961-981.

Lillis, B. and Szwejczewski, M. (2012), “An exploratory study of strategic operations audit method in services", International journal of Operations \& Production Management, Vol.32, No.11, pp.1306-1336.

Linderman, K., Schroeder, R.G. and Choo, A.S. (2006), "Six Sigma: The role of goals in improvement teams", Journal of Operations Management, Vol.24, No.6, pp.779-790. 
Macher, J.T. and Mowery, D.C. (2009), "Measuring dynamic capabilities: practices and performance in semiconductor manufacturing”, British Journal of Management, Vol.20, S41-S62.

McAdam, R. Humphreys, P., Galbraith, B. and Miller, K. (2017), "Developing management capability within a horizontal supply chain in performance measurement deployment and evolution: a Dynamic Capabilities and Goal Theory perspective”, Production Planning and Control, Vol.28, No.6-8, pp.610-628.

MellatParast, M. (2011), "The effect of Six Sigma projects on innovation and firm performance”, International journal of Project Management, Vol.29, pp.45-55.

Modarres, M. and Pezeshk, J. (2017). "Impact of total quality management on organisational performance: exploring the mediating effects of organisational learning and innovation”. International Journal of Business Environment, Vol.9, No.4, pp.356-389.

Molina, L. M., Lloréns-Montes, J. and Ruiz-Moreno, A. (2007), "Relationship between quality management practices and knowledge transfer", Journal of Operations Management, Vol.25, pp.682-701.

Mulaik, S.A., James, L.R, Alstine, J., Bennett, N., Lind, S. and Stilwell, C. (1989), "Evaluation of Goodness-of-Fit for Structural Equation Models", Psychological Bulletin, Vol.105 No.3, pp.430.

Nair, A., Malhotra, M.K. and Ahire, S.L. (2011), "Toward a theory of managing context in Six Sigma process-improvement projects: An action research investigation", Journal of Operations Management, Vol.29, pp.529-548. 
Newey, L.R. and Zahra, S.A. (2009), “The evolving firm: how dynamic and operating capabilities interact to enable entrepreneurship", British Journal of Management, Vol.20, S81-S100.

Newey, L., Verreynne, M. and Griffiths, A. (2012), “The relationship between dynamic and operating capabilities as a stage-gate process: insights from radical innovation”, Journal of Management \& Organization, Vol.18, pp.123-140.

Nielsen, A.P. 2006. "Understanding dynamic capabilities through knowledge management”. Journal of Knowledge Management 10:59-71.

Padhy, R.K. and Sahu, S. (2011), “A real option based Six Sigma project evaluation and selection model", International journal of Project Management, Vol.29, pp.1091-1102.

Pathiratne, S., Khatibi, A. and Johar, M. (2018), "CSFs for Six Sigma in service and manufacturing companies: an insight on literature", International Journal of Lean Six Sigma, Vol.9, No.4, pp.543-561

Pagell, M. and Krause, D.R. (1999), “A multiple-method of environmental uncertainty and manufacturing flexibility", Journal of Operations Management, Vol.17, pp.307-325.

Pagell, M. and Krause, D.R. (2004), "Re-exploring the relationship between flexibility and the external environment", Journal of Operations Management, Vol.21, pp.629-649. Pande, P. S., Neuman, R. P. and Cavanagh, R.R. (2000), The Six Sigma way. McGraw Hill, New York.

Pavlou, P.A. and El Sawy, O.A. (2011), "Understanding the elusive black box of dynamic capabilities", Decision Sciences, Vol.42, pp.239-273.

Petter, S., Straub, D., and Rai, A. (2007). "Specifying formative constructs in information systems research”. MIS Quarterly, Vol.31, No.4, pp.623-656. 
Preacher, K. J. and Hayes, F. (2008), “Asymptotic and resampling strategies for assessing and comparing indirect effects in multiple mediator models", Behavior Research Methods, Vol.40, pp.879-891.

Protogerou, A., Caloghirou, Y. and Lioukas, S. (2012), "Dynamic capabilities and their indirect impact on firm performance", Industrial and Corporate Change, Vol.3, pp.615647.

Reosekar, R. and Pohekar, S. (2014), "Six Sigma methodology: a structured review", International Journal of Lean Six Sigma, Vol.5, No.4, pp.392-422.

Reuter, C., Foerstl, K., Hartmann, E. and Blome, C. (2010), “Sustainable global supplier management: the role of dynamic capabilities in achieving competitive advantage", Journal of Supply Chain Management, Vol.46, No.2, pp.45-63.

Sanchez, R. (1995), "Strategic flexibility in product competition”, Strategic Management Journal, Vol.16, pp.165-159.

Schilke, O. (2014), "On the contingent value of dynamic capabilities for competitive advantage: the nonlinear moderating effect of environmental dynamism", Strategic Management Journal, Vol.35, No.2, pp.179-203.

Schroeder, R. G., Linderman, K., Liedtke, C. and Choo, A. S. (2008), "Six Sigma: Definition and underlying theory", Journal of Operations Management, Vol.26, pp.536554.

Sethi, A.K. and Sethi, S.P. (1990), "Flexibility in Manufacturing”, International Journal of Flexible Manufacturing Systems, Vol.2 No.4, pp.289-328. 
Shafer, S. M. and Moeller, S. M. (2012), "The effects of Six Sigma on corporate performance: An empirical investigation", Journal of Operations Management, Vol.30, pp.512-532.

Shimizu, K. and Hitt, M. A. (2004), "Strategic flexibility: organizational prepared mess to reverse ineffective strategic decisions", Academy of Management Executive, Vol.18, pp.44-59.

Schroeder, R. G., Linderman, K., Liedtke, C. and Choo, A. S. (2008), "Six Sigma: Definition and underlying theory", Journal of Operations Management, Vol.26, pp.536554.

Sin, A., Zailani, S., Iranmanesh, M. and Ramayah, T. (2015), "Structural equation modelling on knowledge creation in Six Sigma DMAIC project and its impact on organizational performance", International Journal of Production Economics, Vol.168, pp.105-117.

Sinkula, J.M., Baker, W.E. and Noordewier, T.A. (1997), "Framework for market-based organizational learning: linking values, knowledge, and behaviour", Journal of Academy Marketing Science, Vol.25, No.4, pp.305-318.

Sunder, V. and Antony, J. (2015), "Six-sigma for improving Top-Box Customer Satisfaction score for a banking call centre", Production Planning and Control, Vol.26, No.16, pp.1291-1305.

Swink, M. and Jacobs, B.W. (2012), "Six Sigma adoption: Operations performance impacts and contextual drivers of success", Journal of Operations Management, Vol.30, No.6, pp.437-453. 
Szulanski, G. (1996), "Exploring internal stickiness: impediments to transfer of best practice within the firm", Strategic Management Journal, Vol.17, pp.27-43.

Tamayo-Torres, I., Gutierrez-Gutierrez, L. and Ruiz Moreno, A. (2019). "Boosting Sustainability and Financial Performance: The Role of Supply Chain Controversies”. International Journal of Production Research. Forthcoming.

Teece, D.J. (2007), "Explicating dynamic capabilities: the nature and microfoundations of No.sustainable) enterprise performance", Strategic Management Journal, Vol.28, No.13, pp.1319-1350.

Teece, K., Pisano, G. and Shuen, D. (1997), "Dynamic capabilities and strategic management”, Strategic Management Journal, Vol.18, No.7, pp.590-533.

Thawani, S. (2004), "Six Sigma - Strategy for organizational excellence”, Total Quality Management, Vol.15, No.5, pp.655-664.

Verdu-Jover, A.J., Llorens-Montes, F.J. and Garcia-Morales, V.J. (2004), “The concept of fit in services flexibility research: an empirical approach", International Journal of Service Industrial Management, Vol.15 No.5, pp.499-514.

Verona G. and Ravasi D. (2003), “Unbundling Dynamic Capabilities: An Exploratory Study of Continuous Product Innovation", Industrial and Corporate Change, Vol.12, No.3, pp.577-606.

Vogel, R. and Güttel, W.H. (2012), "The dynamic capability view in Strategic Management: a bibliometric review". International journal of Management Review, Vol.15, No.4, pp.426-446.

Volberda, H.W. (1996), "Toward the flexible form: How to remain vital in hypercompetitive environments". Organization Science, Vol.17, No.4, pp.359-374. 
Volberda, H.W. (1999), Building the Flexible Firm: How to remain Competitive. Oxford University Press, New York, NY.

Wang, C.L. and Ahmed, P.K. (2007), "Dynamic capabilities: a review and research agenda", International journal of Management Review, Vol.9, pp.31-51.

Wiklund, H. and Wiklund, P.S. (2002), "Widening the Six Sigma concept: an approach to improve organizational learning”, Total Quality Management, Vol.13, No.2, pp.233239.

Winter, S. (2003), "Understanding dynamic capabilities", Strategic Management Journal, Vol.24, No.10, pp.991-995.

Witcher, B.J., Chau, V.S. and Harding, P. (2008), "Dynamic capabilities: top executive audits and hoshinkanri at Nissan South Africa”, International journal of Operations \& Production Management, Vol.28, No.6, pp.540-561.

Wu, C. and Lin, C. (2009), "Case study of knowledge creation facilitated by Six Sigma", International Journal of Quality \& Reliability Management, Vol.26, pp.911-932.

Zahra, S.A., Sapienza, H.J. and Davidsson, P. (2006), "Entrepreneurship and dynamic capabilities: a review, model and research agenda", Journal of Management Studies, Vol.43, pp.917-955.

Zahra, S. and George, G. (2002), “Absorptive Capacity: A review, reconceptualization, and extension", Academy of Management Review, Vol.22 No.2, pp.185-203.

Zhang, A., Luo, W., Shi, Y., Chia, S. and Sim, Z. (2016), "Lean and Six Sigma in logistics: a pilot survey study in Singapore", International Journal of Operations and Production Management, Vol.36, No.11, pp.1625-1643. 
Zheng, S., Zhang, W., Wu, X. and Du, J. D. (2011), "Knowledge-based dynamic capabilities and innovation in networked environments", Journal of Knowledge Management, Vol.15, pp.1035-1051.

Zhou, K.Z. and Li, C.B. (2010), "How strategic orientations influence the building of dynamic capability in emerging economics”, Journal of Business Research, Vol.63, No.3, pp.224-231.

Zollo, M. and Singh, H. (2004), "Deliberate learning in corporate acquisitions: postacquisition strategies and integration capability in U.S. bank mergers", Strategic Management Journal, Vol.25, pp.1233-1256.

Zollo, M. and Winter, S.G. (2002), "Deliberate learning and the evolution of dynamic capabilities”, Organization Science, Vol.13, No.3, pp.339-351.

Zu, X., Fredendall, L.D. and Douglas, T.J. (2008), "The evolving theory of quality management: the role of Six Sigma", Journal of Operations Management, Vol.26, pp.630-650.

Appendix A. Measurement scales

Teamwork management:

1. Supervisors encourage the persons who work for them to exchange opinions and ideas.

2. Supervisors encourage the people who work for them to work as a team.

3. Supervisors frequently hold groups meetings where the people who work for them can really discuss things together.

Statistical metrics usage:

1. Statistical metrics are used extensively in our plant.

2. Statistical metrics have been effective in improving the quality of our primary product.

3. We will continue to use statistical metrics in the manufacture of our primary product. 
Absorptive capacity:

1. The new knowledge acquired is in agreement with existing knowledge in the organisation.

2. Organization has a clear division of roles and responsibilities to exploit new knowledge.

3. Organization has the necessary skills to use new knowledge obtained.

4. Organization has the technical competence to absorb new knowledge.

5. Organization has the managerial competence to absorb new knowledge.

6. It is well known who can best exploit new information and new knowledge.

Knowledge integration:

1. The rules and/or policies in the firm enable the co-ordination of activities and information flows.

2. Our firm has production activities divided into independent phases and organised sequentially.

3. There are generally accepted behaviour patterns that govern actions when rules and procedures do not.

4. To resolve complex situations and uncertainty, we organise conflict resolution and decision-making groups.

5. The rules, sequences, behaviour patterns and groups enable sharing of useful knowledge among members of the firm and avoid unnecessary.

Organizationallearningorientation:

1. Our organization is a learning organization.

2. The sense around here is that employee learning is an investment, not an expense.

3. Once we quit learning, we endanger our future.

4. The basic values of this organization include learning as a key to improvement.

5. Our ability to learn is the key to improvement.

Operational flexibility:

1. The ability of the computer systems to process and distribute information and present it in the right way and at the right moment to the person who requested.

2. The number of different tasks that the computer system enables the available computers or terminals to perform for personnel.

3. The computer system enables efficient exchange of information between system computers and terminals.

Strategic flexibility:

1. In our firm we re-formulate dismantle current strategies quickly when market conditions or competence require it. 
3. In our firm we use production machinery or providing of services technologies that allow a large amount of operations quickly and without large costs of task change.

4. In our firm we introduce a large number of modifications over products or services every year. 